Open Access

\title{
Determinants of food insecurity in the rural farm households in South Wollo Zone of Ethiopia: the case of the Teleyayen sub- watershed
}

\author{
Alem-meta Assefa Agidew ${ }^{1 *}$ and K. N. Singh ${ }^{2}$
}

* Correspondence: alexasfaw23@ gmail.com

'Department of Geography and Environmental Studies, Wollo University, P.O. Box 1145, Dessie, Ethiopia

Full list of author information is available at the end of the article

\begin{abstract}
This study evaluated determinants of food insecurity in the rural farm households of the Teleyayen sub-watershed in Ethiopia. The study used a multistage sampling procedure to select 215 sample households involving a combination of purposive and random sampling. Data were collected using structured survey questionnaire, focus group discussion (FGD), and key informant interviews. Independent sample $t$ test, chi-square, percentage, mean, and standard deviation were employed to analyze the data. It was found that 20.9 and $79.1 \%$ of the sample households are food secure and food insecure, respectively. The majority of the food insecure households were younger household heads, who own less than 1 ha of farmlands. On average, male-headed households were more food secure than female-headed households. The result of the binary logistic regression revealed that shortage of farmland, poverty, recurrent drought and climate change, shortage of rainfall, and land degradation are determining factors for such food insecurity. However, the gender of household head, policy support, land redistribution, farmland topography, soil fertility, and erosion do not show any significant influence.
\end{abstract}

Keywords: Food insecurity, Binary logistic regression, Rural household, Ethiopia

\section{Background}

Ethiopia is one of the poorest countries in the world, and about $90 \%$ of the populations live in the rural areas. In this layer, more than half suffer from food insecurity (Barnett 2001). Similarly, Doocy et al. (2005) indicated that poverty and food insecurity are endemic and are exacerbated by the frequent droughts that plague the region, wars, and lack of public policy. In response to the threat of declining crop yield and food security, farmers react in a number of ways and adopt several land management technologies (Gafsi and Brossier 1997). Normally, they concentrate their conservation efforts on soils which are susceptible to high rates of erosion (Ervin and Ervin 1982; Paudel 2001). According to Feleke et al. (2005), seven factors affect household food security in Ethiopia. These are the technology used, farming systems, farm size, soil quality, family size, aggregated per capita production, and access to markets. A study conducted by Holden et al. (2005) also revealed that soil degradation is extensive, reducing the average agricultural production and increasing the farmers' vulnerability to drought.

(c) The Author(s). 2018 Open Access This article is distributed under the terms of the Creative Commons Attribution 4.0 International License (http://creativecommons.org/licenses/by/4.0/), which permits unrestricted use, distribution, and reproduction in any medium, provided you give appropriate credit to the original author(s) and the source, provide a link to the Creative Commons license, and indicate if changes were made. 
Rural food insecurity is one of the defining features of rural poverty, particularly in the moisture-deficit northeast highland plateaus and some pastoral areas of Ethiopia (MOFED 2002). The study area, the Teleyayen sub-watershed, is among these areas, which is mostly affected by food insecurity, land degradation in the form of soil erosion and nutrient depletion. Moreover, the area is prone to low and erratic rainfall and frequent droughts. Most cultivated lands in the sub-watershed are suffering from loss of topsoil leaving bare stones behind. Such a loss is linked with reduced crop and livestock productivity and forces farmers to move to native and intact ecosystems of the landscape and marginal lands to develop new farmlands. Thus, to establish the full picture of food security, land degradation, and economic benefits of sustainable land management, a greater understanding of food insecurity drivers and impacts at the sub-watershed level is needed.

Most of the studies that have been done so far on the issues of food security in Ethiopia are very general and consider the problem from national, regional, and district points of view. While aggregate data are generally available at the national level, little work has been done to understand the food security problems at the household level in specific sub-watershed. Having national food balance data is not sufficient to understand determinants of food insecurity in rural farm households in the country. Most agricultural production comes from millions of rural households. Despite the increasing global concern of improving food security, the nature and extent of food security at the household level in rural areas are not well documented. The main objective of this study was, therefore, to examine the determinants of food insecurity in the rural farm households in Ethiopia using the Teleyayen sub-watershed as a case study. The specific objectives were to investigate the food security status of the rural households and to assess the extent and magnitude of rural farm household's food insecurity in the study area. To the best of my knowledge, there are no studies done on assessing such determining factors in this particular sub-watershed. Therefore, this study was conducted in order to fill this gap by sharing robust empirical evidence on determinants of food insecurity and household food security status in the Teleyayen sub-watershed. The result of this study is intended to be useful for policy-makers, land use planners, and development practitioners in Ethiopia in general and in the study area in particular, who are seeking to understand how best to respond to the problems of food insecurity by identifying their major determinants. As a result, the findings will allow them to redesign better land use and land management practices that could motivate farmers to produce more food crops to improve their food supply. Moreover, farmers will be able to gain adequate knowledge on understanding the best ways of alleviating the problems of food security.

\section{Food security and food insecurity situations of Ethiopia}

The concept of food security has been defined on numerous occasions by the international community, and it has evolved considerably over time. The consensus that has emerged from the global debate is that: "Food security, at the individual, household, national, regional, and global levels is achieved when all people, at all times, have physical and economic access to sufficient, safe, and nutritious food to meet their dietary needs and food preferences for an active and healthy life" (FAO 1996). In contrast, food insecurity exists when all people at all times have no physical and economic access to 
sufficient or adequate, safe, and nutritious food to meet their dietary needs and food preferences for an active and healthy life (Phillips and Taylor 1990). Food security is a concept that encompasses four main dimensions, namely availability in sufficient quantity of food of an appropriate nature and quality in all parts of the national territory, irrespective of its origin (local production, imports, or food aid), access by all people to the resources required to be able to acquire the food needed by them for an nutritionally adequate diet. These resources include not only financial resources but also rights of access to the resources required to produce food or to receive it from others; stability of access to food, i.e., the assurance of access by people to food even in the face of natural or economic shocks; and a satisfactory utilization of food by people that is not inhibited by health or hygiene problems (safe drinking water, sanitation or medical services, etc.).

\section{Drivers of food insecurity}

Discussions about causes of food insecurity in Ethiopia have always been complex (Webb et al. 1992; Markos 1997) given that multiple factors affect food security. However, drought risk remains one of the key drivers of food insecurity in Ethiopia. Since 1950, 12 major drought-induced food security crises have occurred, highlighting the sensitivity of food security to climate-related risks. According to Woldeamlak (2009), once every 3 or 4 years is a drought year in Ethiopia. Environmental degradation is also a critical factor which exacerbates soil loss, deforestation, and pest incidence-all of which affect food security. In addition, rapid population growth, poverty, rural-urban migration, and conflict can contribute to food insecurity.

\section{Methods}

\section{Geographic location of the study area}

This research was conducted in the Teleyayen sub-watershed, which is located in South Wollo Zone, which is one of the 11 administrative zones of the Amhara National Regional State of Ethiopia. The reasons for the selection of the site for this study include: the watershed is part of the northeastern highlands of Ethiopia, which is historically known to be food insecure and highly threatened by severe resource degradation; as far as my reading is concerned, no study has been carried out on the issues of food security in this particular sub-watershed. This may be because of the ruggedness of the topography of the study area. Thus, it needs intervention as soon as possible.

The study area is located in Kutaber and Ambasel woredas (districts). It lies partly in Kutaber and partly in Ambasel districts. It covers a total area of $152 \mathrm{~km}^{2}$. Of this, Kutaber district shares $125 \mathrm{~km}^{2}(82 \%)$ and Ambasel shares $27 \mathrm{~km}^{2}$ (18\%). Geographically, the sub-watershed is located between $11^{\circ} 14^{\prime} 30^{\prime \prime} \mathrm{N}$ and $11^{\circ} 29^{\prime} 30^{\prime \prime} \mathrm{N}$ latitude and $39^{\circ} 21^{\prime} 0^{\prime \prime} \mathrm{E}$ and $39^{\circ} 33^{\prime} 0^{\prime \prime} \mathrm{E}$ longitude (Fig. 1) and is about $441 \mathrm{~km}$ north of Addis Ababa (the capital city) and about $40 \mathrm{~km}$ northwest of Dessie Town, on the Dessie-Kutaber-Delanta Road. It is characterized by diverse topographic conditions that form part of the headstream of the Abay (Blue Nile) basin. Its elevation ranges from 1703 to $3406 \mathrm{~m}$ above sea level. The total population of the study area is about 20,296 distributed within eight rural ${ }^{1}$ kebeles, namely Doshign, Aba Selama, Asecha, Kundina Jerjero, Amba-gebi, Manosh (in Kutaber district), Delba, and Teregma (in Ambasel district). Its total population is der0ived from the total area and total population of the 


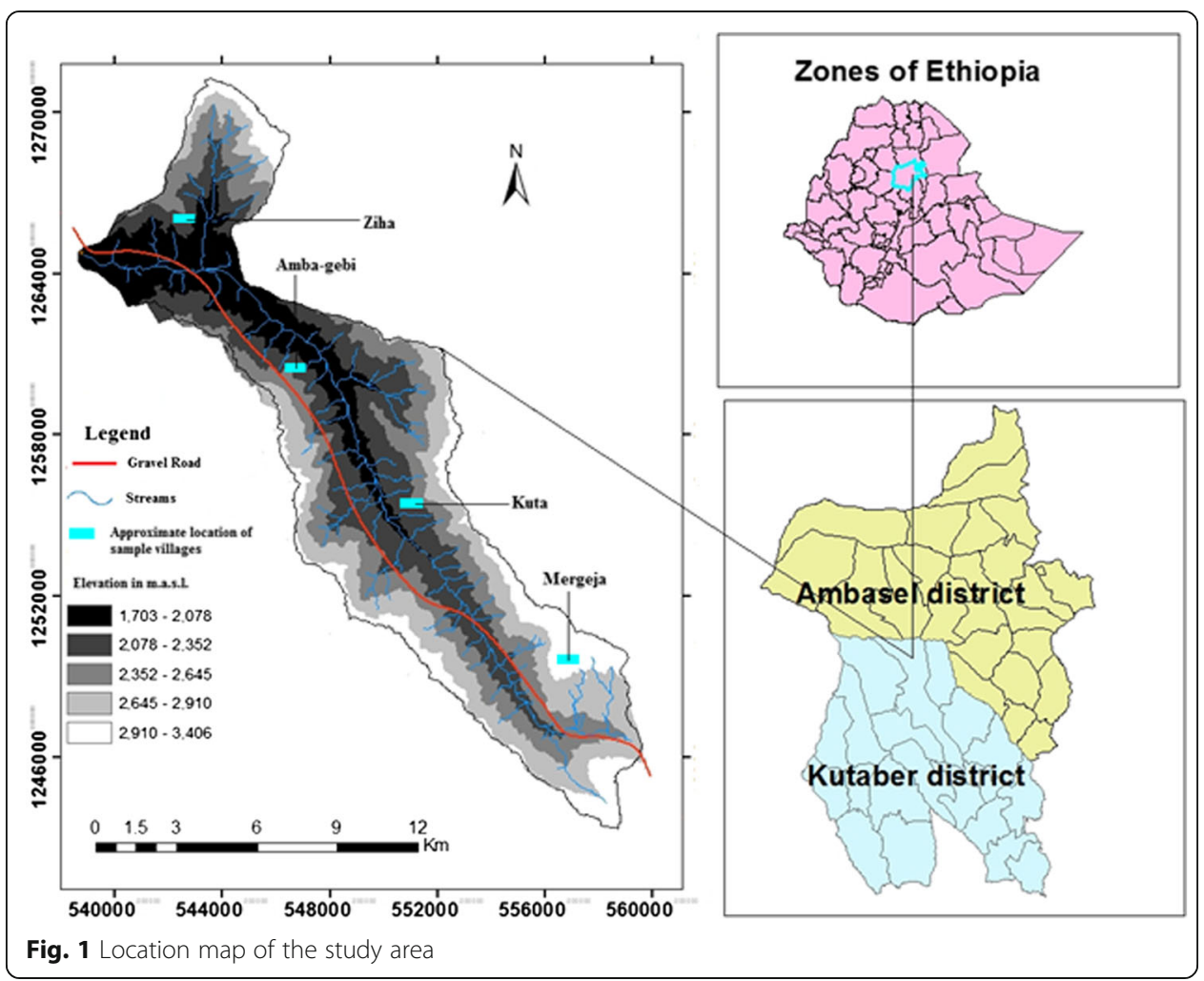

two districts (CSA 2007). A mountainous and highly dissected terrain with steep slopes characterizes most parts of the sub-watershed.

Since soil characteristic is one of the important aspects of crop productivity, it is essential to understand about its geographical distribution, types, and fertility. But, as scientific literature on soils of the study area is lacking, the local names, farmers' perception of soil types, and fertility characteristics could not be supplemented by scientific verifications. Nevertheless, attempts have been made to assimilate the local definitions with that of FAO soil characteristics based on its nomenclatures of soils.

According to FAO/WFP (1995), dominant soil types of the Amhara Region include black vertisols $(43 \%)$ and black non-vertisols (27\%). Soils of Wollo area vary greatly in their ecological properties, depending on parent substrate, grain size, composition, humus contents, relief profiles, and depth to groundwater. Hence, this area has various soil types, the major soils being leptosols, cambisols, vertisols, andosols, and luvisols (FAO 1984). According to the Ministry of Agriculture soil type classification, soils that cover much of the Teleyayen sub-watershed area are leptosols, eutric cambisols, and eutric regosols. The sub-watershed is drained by the headwaters of the Teleyayen River and its tributaries and finally entering into the Beshillo River, which forms part of the upper Abay (Blue Nile) basin. It is characterized by mountainous and highly dissected terrain with steep slopes (Fig. 2).

Based on Koppen's classification, the Wollo area is classified into three climatic regions: cool highland climate, tropical climate with dry summer, and tropical climate with distinct dry winter. Wollo also has three distinct seasons, namely winter, summer, and spring. Winter is a dry season from October to January (NMSA 1996). Spring is the small rainy season that occurs between mid-February and mid-May, while summer 


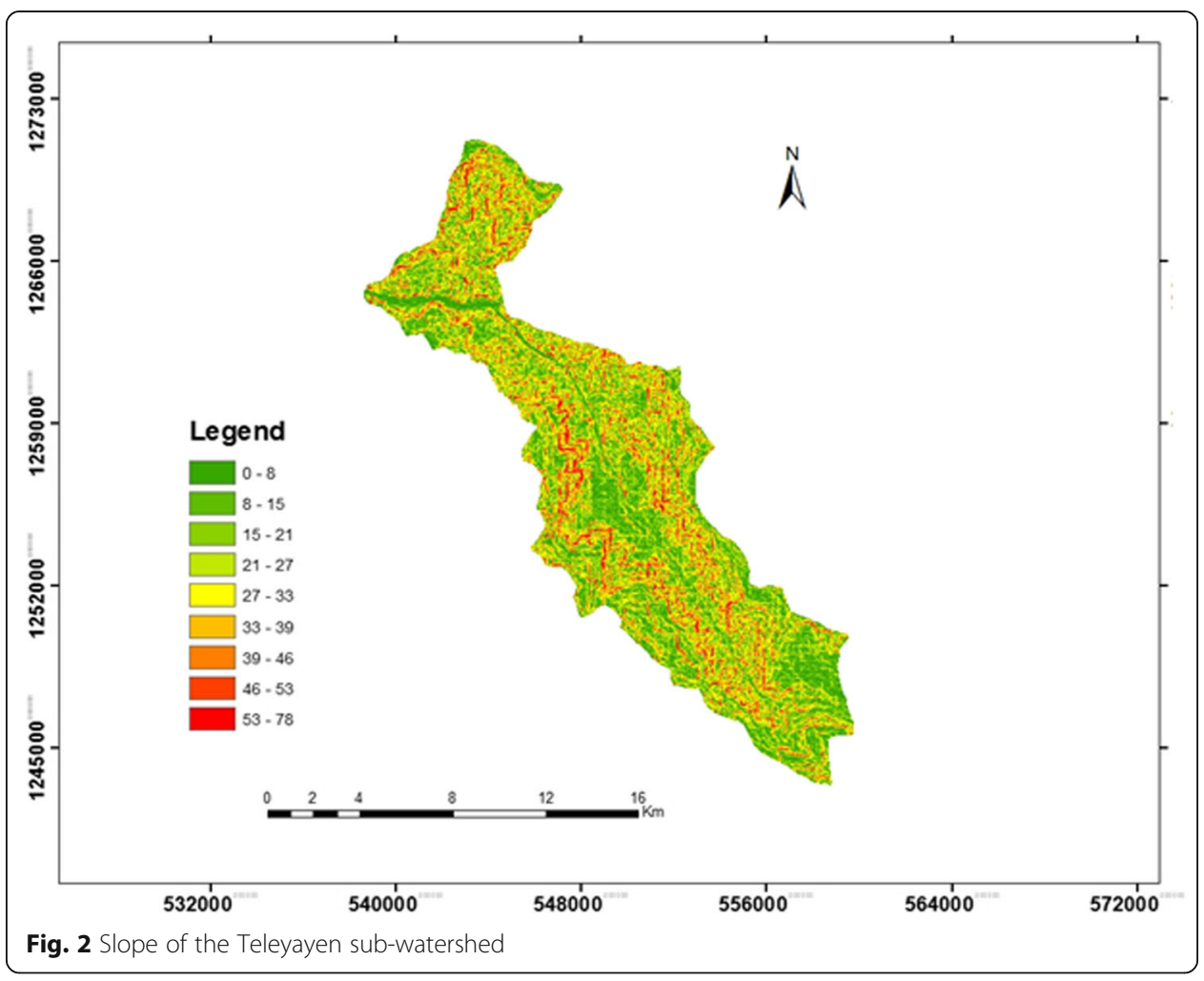

is the main rainy season that extends from mid-June to mid-September (NMSA 1996). The mean annual temperature and mean annual rainfall of Wollo area range from 14 to $20{ }^{\circ} \mathrm{C}$ and from 680 to $1200 \mathrm{~mm}$, respectively (Gonfa 1996). Based on the moisture index, the climate of Wollo is classified as dry with arid to dry sub-humid conditions. According to the climatic characteristics, the region is further subdivided into an eastern and western part. Eastern Wollo has a relatively dry climate with a moisture index of minus 60 to 0 , and most areas receive sufficient moisture during the rainy seasons with some surplus water. In contrast, western Wollo has a moderate to a large amount of water surplus in the rainy seasons, which results in a high runoff, soil erosion, and waterlogging depending on the soil type and topography (Gonfa 1996).

The meteorological data used for this study was obtained from Kombolcha Meteorological Station, recorded for Dessie site. Hence, the mean annual temperature of the Teleyayen sub-watershed is about $16{ }^{\circ} \mathrm{C}$, and the average annual total rainfall is $1133 \mathrm{~mm}$ (taking into account the whole seasons of a year) (Fig. 3). More than 58\% of the total rain falls in 2 months of July and August (summer season), while 18\% falls in the spring season (March, April, and May), and less than 5\% of the total occurs during the dry months of December, January, and February (winter season). The uneven distribution of the rainfall gives rise to a serious shortage of water during the dry season particularly in the lower parts of the sub-watershed.

Basically, the economy of rural households in Ethiopia depends on agriculture, be it dominantly pastoral, arable, or mixed farming system. Like other parts of the Ethiopian highlands, the major farming system of Wollo is mixed cereal-livestock (Haileslassie et al. 2005). The farming system is diversified and determined by agro-ecology. Cereals are the dominant crop accounting for over $73 \%$, followed by pulses $(24 \%)$, and the 


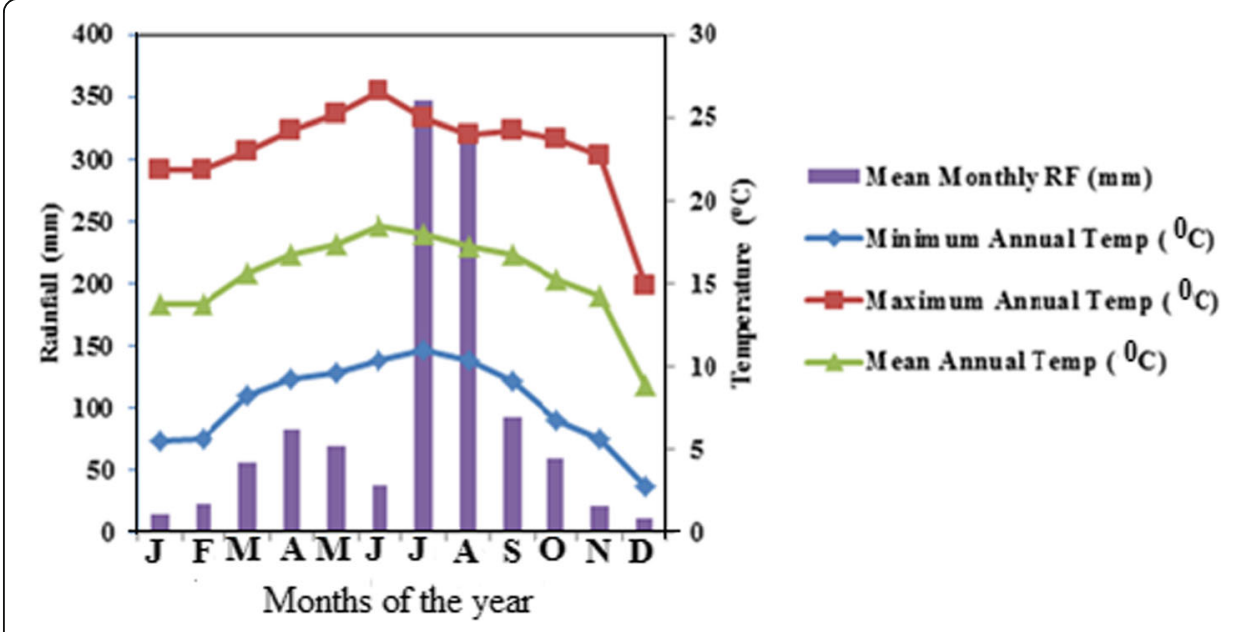

Fig. 3 Min., max., and mean annual temperature and mean monthly rainfall of the study area

remaining 3\% is oilseed (ANRS-BFED 2008). Among the cereal crops, tef (Eragrostis tef), sorghum (Sorghum spp.), wheat (Triticum vulgare), and barley (Hordeum vulgaris) are dominant, accounting for $25,18,16$, and $11 \%$ of the total, respectively (ANRSBFED 2008).

Likewise, rural households in the Teleyayen sub-watershed carry out mixed agriculture where crop production and livestock rearing are simultaneously practiced. Land and livestock are therefore the most important assets of the people, with which they lead a sedentary life. Livestock provides the draught power and household members, the labor that is needed for farming operation. The land is a scarce resource due to high population pressure and land degradation. Most of the agricultural produce is for the farm household's own consumption. The farming is carried out using rain-fed systems, but a small-scale irrigation project has begun recently in the sub-watershed.

A variety of crops is produced by every household because of the strong orientation towards self-sufficiency. Crop production follows a bimodal rainfall regime (short spring and longer summer rains) leading to two harvest periods, but the spring harvest is by far the most important. This is because of the combination of rugged topography and intense summer rains which permit cultivation on the areas with a gentle slope, which covers only small areas. Major crops grown in the sub-watershed include tef (Eragrostis tef), wheat (Triticum vulgare), barley (Hordeum vulgaris), oats (Avena sativa), horse beans (Vicia faba), peas (Pisum sativum), potato (Solanum tuberosum), maize (Zea mays), sorghum (Sorghum spp.), pepper (Piper nigrum), and onion (Allium сера). Spring rains are used for growing wheat, barley, and pulses between January and April. Also, some villages in the lowlands take advantage of spring rains to cultivate tef. Spring rains are also important for farmers in the mid-highland for growing long maturing varieties of tef, sorghum, and maize. Crop production is, therefore, the major source of income to the households. Incomes from off-farm employment include petty trading, charcoal and firewood selling, weaving, and pottery. The livestock types include cattle, sheep, goats, pack animals, and poultry. The average landholding size per family is 0.5 ha on which mixed crop and livestock farming are practiced (UNDP 1994). 


\section{Data collection and analysis}

The study was conducted based on the data that were obtained through a farm household survey administered to 215 sample farm household heads drawn through multistage sampling technique. The target populations for the study were farmers who cultivate crops, vegetables, and fruits within the Teleyayen sub-watershed. A sampling frame is a list that identifies the target population (Kothari 2004). The sampling frame for this study was obtained from the selected sample kebele administration offices.

The data used for this study were derived from both primary and secondary sources. Primary data were collected through household questionnaire, focus group discussions, key informant interview, and personal field observations, while secondary data were collected from relevant local authority reports, books, and journals. Questionnaire data, which is gathered from respondents, was quantitatively analyzed, summarized, and presented in tables, graphs, and percentages.

The questions included in the survey questionnaire were both closed-ended and open-ended types. The questionnaire was administered during January and February 2016. This period was chosen mainly because it is an ideal time when farmers have completed their harvesting activities and start the natural resource development program works at the watershed level, which is carried out yearly by organized government support schedule. Hence, it is easy to interview the sample farm households and collect the required data. Before full implementation, the questionnaire was pre-tested as a pilot survey in the sample villages. The pilot tests of questions were made by distributing the questionnaire to four household heads in each sample kebele in order to know whether the instruments are appropriate and suit to the intended study. Hence, necessary adjustments were made based on the comments obtained from pre-test responses from farmers to ensure reliability and validity of the questionnaire. Secondary data were also collected from books, journals, and internet sources.

A modified form of a simple equation termed as Household Food Balance Model was used to measure the sample households' food security. It involves the measurement of the average daily food available to each person in a sample household. After data collection, the researcher has converted the households' annual available food grain supply into kilograms and then based on the conversion factors of major cereals converted into kilocalories. The converted results were then divided by the household size as adult equivalent and the number of days in the recall period. Moreover, the data were also analyzed using descriptive and inferential statistics Module of the Statistical Package for Social Sciences (SPSS-IBM) software, version 21. Descriptive statistics were used to show the effects of continuous and descriptive variables of the study on sample household food security, while inferential statistics like binary logistic regression was used to know the association between dependent and independent variables upon determinants of food insecurity in rural farm households.

\section{Results and discussion}

\section{Household's food security measurement}

While accurate measurement of household food security is essential for effective research and well-targeted policies and programs, there is no standard methodology for measuring food security, and despite an improved theoretical understanding of food 
security, the FAO notes that there exists no "perfect single measure that captures all aspects of food insecurity" (FAO 2002). Instead, a household's level of food insecurity or hunger must be determined by obtaining information on a variety of specific conditions, experiences, and behaviors that serve as indicators of the varying degrees of severity of the condition. Household surveys, usually conducted in person or by telephone, are used to get this information. Research over the past two decades has identified a particular set of this kind of condition, experience, and behavior pattern that consistently characterizes the phenomenon of food insecurity and hunger (Derrickson 2000).

According to Bouis (1993), two approaches have been commonly used in measuring household food consumption. The first is expenditure technique that estimates gross household's production and purchases over the given time. Estimates of the increase or reduction of food stocks held over time are made, and the balance is considered as consumed by the household. The limitation of expenditure survey is that it tends to underestimate expenditures on food if the value of food produced at home or gathered locally is not recorded or recalled. The second method uses a recall method to measure the amount of food consumed by the household members during $24 \mathrm{~h}$. This technique, in relation to the expenditure method, gives more reliable household consumption information, but it is costly due to the considerable time required for collecting the data.

In this study, a modified form of a simple equation termed as Household Food Balance Model, originally adapted by (Degefa 1996) from FAO Regional Food Balance Model and thenceforth used by different researchers in this field (Eshetu 2000; Messay 2009), was used to calculate the per capita food available.

\section{Household food balance model}

$$
\mathrm{NGA}=(\mathrm{GP}+\mathrm{GB}+\mathrm{FA}+\mathrm{GG})-(\mathrm{HL}+\mathrm{GU}+\mathrm{GS}+\mathrm{GV})
$$

where NGA = net grain available/year/household, GP = total grain produced/year/ household, $\mathrm{GB}=$ total grain bought/year/household, FA = quantity of food aid obtained/year/household, GG = total grain obtained through gift or remittance/year/ household, HL = post-harvest losses/year, GU = quantity of grain reserved for seed/ year/household, GS = amount of grain sold/year/household, and GV = grain given to others within a year.

The single most important indicator of food adequacy level of a community is the per capita dietary energy supply measured in kilocalorie. This is the measure of the average daily food available to each person in a sample household. Consequently, after data collection from sample respondents, the researcher has converted the households' annual available food grain supply into kilograms and then by using the conversion factors of major cereals; they were changed into kilocalories. This was done after computing the balance between grains gained and lost using the simple Household Food Balance Model indicated above. The converted results were then divided by the number of household members as adult equivalent and the number of days in the recall period.

Consequently, the results were compared with the minimum requirements per day per adult equivalent unit (AEU). According to Kaluski et al. (2002), the minimum daily recommended food energy intake of $2100 \mathrm{kcal}$ per AEU was used as the cutoff level for classifying households into food secure and food insecure. Hence, households whose caloric consumption is greater than or equal to $2100 \mathrm{kcal} /$ day/AEU were categorized as 
food secure. On the other hand, households whose caloric consumption is less than $2100 \mathrm{kcal} /$ day/AEU were categorized as food insecure.

After categorizing households as food secure and insecure, the next step was to identify variables that have an association with food security at household level. The dependent variable (household food security) is dichotomous in nature (food secure and food insecure households); the binary logistic regression model was used as the estimated probabilities that lie between the logical limit of 0 and 1 (Gujarati 1995). Hence, food security statuses were expressed by a binary dependent variable $(0=$ food insecure households and $1=$ food secure households).

A household is food secure when it shows no or minimal evidence of food insecurity, while it is food insecure when all households with children have reduced the children's food intake to an extent indicating that the children have experienced hunger. For some other households with children, this already has occurred at an earlier stage of severity. Adults in households with and without children have repeatedly experienced more extensive reductions in food intake.

\section{The amount of energy available per AEU per day}

The food energy available for the households is compared with the minimum subsistence requirement per AEU/day. Therefore, the percentages of food secure and food insecure sample households were found to be 20.9 and $79.1 \%$, respectively. Hence, the survey results of the study showed that the mean value of the energy available for the food secure and food insecure rural households was 2278 and $1350 \mathrm{kcal} / \mathrm{AEU} /$ day, respectively. The minimum and maximum energy available for food secure households were found to be 2100.9 and $2703.9 \mathrm{kcal}$, respectively. But the minimum and maximum energy available for the food insecure households were found to be 916.2 and 2095. $9 \mathrm{kcal}$, respectively. On the other hand, the standard deviations of the food secure and food insecure households were 159 and 259, respectively. The mean energy intake and standard deviation of the total sample households were $1544.6 \mathrm{kcal}$ and 448.8 , correspondingly. The independent $t$ test value of the total sample households (22.87) approved that there is a significant mean difference between food secure and food insecure rural farm households at $p<0.1$ (Table 1 ).

\section{Statistical summary of continuous variables of the study}

Independent Student's $t$ test was used to examine the group mean difference between food secure and food insecure rural households. Consequently, the means of food secure and insecure households significantly differ only in three of the five continuous variables included in the analysis of the study (Table 2). These variables are family size, the age of the household heads, and household's annual food requirement in kilograms. The independent $t$ test results of these variables were found to be statistically significant at 5\% level of confidence. The statistical analysis of the study showed that the mean family size of food secure households (3.64) is significantly different from the mean family size of food insecure households (4.44). The mean age of food secure household heads (40.51 years) is also significantly different from the mean age of food insecure household heads (44.78 years). Moreover, the mean annual food requirements of food secure households $(843 \mathrm{~kg})$ significantly differ from the mean annual food requirements of food insecure households $(734 \mathrm{~kg})$, with a standard deviation of 325 and 235 , respectively. 
Table 1 Energy available per AEU per day among sample households

\begin{tabular}{llll}
\hline Energy available per AEU in kcal & Food secure $(n=45)$ & Food insecure $(n=170)$ & Total sample $(n=215)$ \\
\hline Minimum & 2100.9 & 916.2 & 916.2 \\
Maximum & 2703.9 & 2095.9 & 2703.9 \\
Mean & 2278 & 1350 & 1544.6 \\
Standard deviation & 159 & 259 & 448.8 \\
$t$ value & - & - & 22.87 \\
\hline
\end{tabular}

Whereas, the independent $t$ test results of livestock size and agricultural labor force were not significant at $5 \%$ level of confidence. This shows that there is no significant difference between the means of the food secure and food insecure rural households of these variables. A study conducted by Bukusuba et al. (2007) in Uganda revealed that large numbers of people in the household are normally seen as equivalent to family labor, and therefore, a large household has the potential of obtaining sufficient labor which is capable of producing more food and therefore becomes food secure. Nonetheless, their argument will only be true if there is no underemployment of the labor force available.

As indicated in Table 3, 47.6\% of sample household heads with 1 to 15 years of farming experience were found to be food insecure as opposed to the rest of the groups. Generally, as the number of farming experience of household heads increases, their probability of being food secure increases. This could be attributed to the fact that because of farmland shortage and fragmentation of the available farmland in the subwatershed, younger household heads own extremely small farm size, which could not allow them to produce the required amount of food crops thereby becomes food insecure. This result agrees with the study conducted by Hofferth (2004). He indicated that the higher the age of the household head, the more stable the economy of the farm household because older people have also relatively richer experiences of the social and physical environment as well as a greater experience of farming activities. Moreover, older household heads are expected to have better access to land than the younger heads because younger men either have to wait for land distribution or have to share the land with their families.

\section{Statistical summary of discrete variables of the study}

The statistical analysis of this study showed that one out of seven discrete variables included in the analysis found to be significant in explaining variations in food security

Table 2 Descriptive statistics of continuous variables

\begin{tabular}{|c|c|c|c|c|c|c|c|}
\hline \multirow[t]{2}{*}{ Variable } & \multicolumn{2}{|c|}{$\begin{array}{l}\text { Food secure } \\
(n=45)\end{array}$} & \multicolumn{2}{|c|}{$\begin{array}{l}\text { Food insecure } \\
(n=170)\end{array}$} & \multicolumn{2}{|c|}{$\begin{array}{l}\text { Total sample } \\
(n=215)\end{array}$} & \multirow[t]{2}{*}{$t$ value } \\
\hline & Mean & SD & Mean & SD & Mean & SD & \\
\hline Family size (AEU) & 3.64 & 1.19 & 4.44 & 1.28 & 4.27 & 1.30 & $-3.749^{*}$ \\
\hline Age of the household head (years) & 40.51 & 13.96 & 44.78 & 11.42 & 43.89 & 12.09 & $-2.125^{*}$ \\
\hline Livestock size & 3.28 & 1.30 & 3.38 & 1.68 & 3.33 & 1.49 & -0.351 \\
\hline Agricultural labor force (numbers) & 2.24 & 1.02 & 2.17 & 0.93 & 2.18 & 0.95 & 0.461 \\
\hline Household's annual food requirements (kg) & 843.48 & 325.23 & 733.96 & 235.18 & 788.72 & 280.20 & $2.55^{*}$ \\
\hline
\end{tabular}

Source: authors' survey result, 2016

*Significant at $5 \%$ 
Table 3 Sample household head's farming experience and their food security status

\begin{tabular}{|c|c|c|c|c|c|c|}
\hline \multirow{2}{*}{$\begin{array}{l}\text { Years of farm } \\
\text { experience }\end{array}$} & \multicolumn{2}{|c|}{ Food secure $(n=45)$} & \multicolumn{2}{|c|}{ Food insecure $(n=170)$} & \multicolumn{2}{|c|}{ Total $(n=215)$} \\
\hline & Frequency & Percent & Frequency & Percent & Frequency & Percent \\
\hline $1-15$ & 24 & 53.3 & 81 & 47.6 & 105 & 48.8 \\
\hline $16-30$ & 15 & 33.3 & 64 & 37.7 & 79 & 36.8 \\
\hline $31-45$ & 4 & 8.9 & 22 & 12.9 & 26 & 12.1 \\
\hline$>45$ & 2 & 4.5 & 3 & 1.8 & 5 & 2.3 \\
\hline Total & 45 & 100 & 170 & 100 & 215 & 100 \\
\hline
\end{tabular}

status between food secure and food insecure farm households (Table 4). This variable is the educational status of the household head.

\section{Educational status of the household head}

The statistical analysis result revealed that 27.4 and $72.6 \%$ of the sample households were found to be literate and illiterate, respectively. Among literate households, 44.4 and $22.9 \%$ were found to be food secure and food insecure, respectively, while 55.6 and $77.1 \%$ of the illiterate households were found to be food secure and food insecure, respectively. The chi-square result of this discrete variable is statistically significant at 95\% (Table 4). This means that there is a significant association between education and food security status. This result indicates the significance of education for household food security improvement because educated household heads are usually practiced

Table 4 Descriptive summary of discrete variables

\begin{tabular}{|c|c|c|c|c|c|c|}
\hline \multirow[t]{2}{*}{ 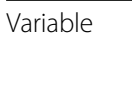 } & \multicolumn{2}{|c|}{ Food secure $(n=45)$} & \multicolumn{2}{|c|}{ Food insecure $(n=170)$} & \multirow[t]{2}{*}{ Chi-square value } & \multirow[t]{2}{*}{ Asymp. sig (2-sided) } \\
\hline & Number & Percent & Number & Percent & & \\
\hline \multicolumn{7}{|c|}{ Education status of the $\mathrm{HH}$ head } \\
\hline Literate & 20 & 44.4 & 39 & 22.9 & 8.26 & $0.004^{*}$ \\
\hline Illiterate & 25 & 55.6 & 131 & 77.1 & & \\
\hline \multicolumn{7}{|c|}{ Gender of the $\mathrm{HH}$ head } \\
\hline Male & 38 & 84.4 & 134 & 78.8 & 0.703 & 0.402 \\
\hline Female & 7 & 15.6 & 36 & 21.2 & & \\
\hline \multicolumn{7}{|c|}{ Access to PSNP } \\
\hline Yes & 10 & 22.2 & 37 & 21.8 & 0.004 & 0.947 \\
\hline No & 35 & 77.8 & 133 & 78.2 & & \\
\hline \multicolumn{7}{|c|}{ Access to credit service } \\
\hline Yes & 31 & 68.9 & 135 & 79.4 & 2.24 & 0.135 \\
\hline No & 14 & 31.1 & 35 & 20.6 & & \\
\hline \multicolumn{7}{|c|}{ Rainfall reliability } \\
\hline Yes & 2 & 4.4 & 8 & 4.7 & 0.005 & 0.941 \\
\hline No & 43 & 95.6 & 162 & 95.3 & & \\
\hline \multicolumn{7}{|c|}{ Access to off-farm income } \\
\hline Yes & 6 & 13.3 & 33 & 19.4 & 0.885 & 0.347 \\
\hline No & 39 & 86.7 & 137 & 80.6 & & \\
\hline \multicolumn{7}{|c|}{ Government support } \\
\hline Yes & 16 & 35.6 & 58 & 34.1 & 0.033 & 0.857 \\
\hline No & 29 & 64.4 & 112 & 65.9 & & \\
\hline
\end{tabular}

Source: authors' survey result, 2016

*Indicates significant level at 0.05 
family planning programs thereby limit their family size when compared with their counterparts and become able to manage food demands of their households. Moreover, they engage themselves and their family members in various non-farm incomegenerating activities. For example, Urassa (2010) argues that households with more education or other forms of human capital stand a better chance of engaging in nonfarm income or credit, and they, therefore, could be more able to afford inputs and thereby becomes more efficient in their farming practices. Hence, farming households with more education had the possibility of obtaining higher yields and become food secure. The result of this variable is consistent with the study done by Koffio-Tessio et al. (2005). They reported that in rural areas, education improves agricultural productivity, leading to food security.

\section{Gender of the household heads}

A majority (80\%) of the sample households were male-headed, while $20 \%$ were femaleheaded. This indicates that there are more male-headed sample households than female-headed households. The chi-square result of this variable indicates that 84.4 and $15.6 \%$ of male-headed and female-headed sample households, respectively, are food secure, whereas 78.8 and $21.2 \%$ of male-headed and female-headed households, respectively, are food insecure. In general, male-headed households are more food secure $(22.09 \%)$ than female-headed households (16.09\%). However, the chi-square result of this variable was found to be insignificant at $95 \%$ level of significance. Hence, there is no correlation between gender of the household head and food security status of the rural farm households. This may be because of the empowerment of rural women in land ownership right and family planning issues because historically, they were marginalized from agricultural investment and family planning activities despite the work they do. This situation has been supported by the study done in India by FAO (2012). It reported that despite rapid economic growth in India, thousands of women and girls still lack food and nutrition security, largely because of deep-rooted gender inequalities in many areas. These deep gender inequalities in food security exist even though women constitute the majority of food producers in the world and are often managing their families' nutritional needs.

\section{Access to Productive Safety Net Program}

In 2005, the government of Ethiopia launched the Food Security Program (FSP), with the Productive Safety Net Program (PSNP) at its center. The PSNP provides transfers (cash or food) to 6-8 million chronically food insecure Ethiopians for 6 months each year, $85 \%$ of whom receive transfers as wages for labor on small-scale public works projects (which are selected by the community and contribute to environmental rehabilitation and local economic development), while 15\% are "direct support" beneficiaries (disabled, elderly, pregnant, or lactating women) who receive unconditional transfers (DFID 2014). This program is expected to enhance sustainable land management by supporting farm households in constructing soil and water conservation practices and increasing farmers' investment capacities in sustainable land management and other public works to ensure the long-term food security of the country.

The statistical analysis result revealed that 21.9 and $78.1 \%$ of the sample households have access and have no access to PSNP, respectively. In this regard, 22.2 and $77.8 \%$ of the food secure households have access to PSNP and have no access to PSNP, respectively. While 21.8 and $78.2 \%$ of the food insecure households have access and have no access to PSNP, respectively. The chi-square result of this variable is statistically insignificant at $95 \%$ 
level of significance. Therefore, there is no association between access to PSNP and food security status of the rural farm households. This could be due to the negligence of the program by the rural farm households because of the insufficient budget allocated for it. This means that instead of participating in PSNP, farmers prefer to work as a daily laborer by migrating to the nearby towns. As a result, PSNP may not help much to improve the food security status of their households.

Access to credit services

This is the ability of households to obtain credit both in cash and kind for either consumption or to support production from lending institutions. The survey result of this study revealed that 77.2 and $22.8 \%$ of the sample households have and do not have access to credit service, respectively. Among these households, 68.9 and $79.4 \%$ were food secure and food insecure, respectively, whereas 31.1 and $20.6 \%$ of the households did not have access to credit service and become food secure and food insecure, respectively. The chi-square result of this variable is statistically insignificant at $95 \%$ level of significance. Therefore, there is no association between access to credit service and food security status of the rural households. This could be because of high-interest rates and farmer's inability to use the credit received for the intended purpose. This result is in line with the report of IFPRI (2009a) that many smallholder farmers in Nigeria are unable to access credit due to the issues of collateral and high-interest rates as well as the short-term and fixed repayment periods for agricultural loans by lending institutions. On the contrary, a study carried out by Pappoe (2011) found that access to credit improves the food security status of farming households among biofuel producers in the central region of Ghana.

Rainfall reliability

The statistical result of this variable showed that $4.7 \%$ of the sample households replied as rainfall was reliable in the area for the last 10 years, whereas the remaining $95.3 \%$ replied as it was not reliable. The chi-square result of this variable is statistically insignificant at $95 \%$ level of significance. Therefore, there is no relation between rainfall reliability and food security status of the rural farm households. This could be due to the inability of farmer's to predict the long-term negative effects of rainfall variability on their food security status.

\section{Access to off-farm income}

Off-farm income includes non-agricultural wages, self-employed income, petty trading, weaving, remittances, charcoal and firewood selling, and handicraft. The survey result of this variable revealed that 18.1 and $81.9 \%$ of the sample households are with and without access to off-farm income, respectively. Of these households, 13.3 and 19.4\% were food secure and food insecure, respectively. While 86.7 and $80.6 \%$ of the households do not have access to off-farm income and become food secure and food insecure, respectively. The chi-square result of this variable is statistically insignificant at 95\% level of significance. Therefore, there is no relationship between access to off-farm income and food security status of the rural households. This could be attributed to the fact that income generated through off-farm activities may not ease the liquidity constraint needed for food security investments or purchase of food crops for bridging the food deficiency of their households. The result of this study is in conformity with the study conducted by Kilic et al. (2009), Goodwin and Mishra (2004), and Chang and Wen (2011). Their findings showed that off-farm income impacted negatively on-farm 
efficiency in different settings. On the contrary, Frankenberger (1992) noted that participation in off-farm activities enables households to modernize their production by giving them an opportunity to apply the necessary inputs and reduces the risk of food shortage during periods of unexpected crop failures through food purchases.

\section{Government support}

Government support includes agricultural extension services, technology transfer (such as advice on food crop production, cash cropping, livestock production, and soil and water conservation), irrigation and water harvesting schemes, the education of women and children, provision of clean water and healthcare, and a stable functioning market system. The survey result of this discrete variable revealed that 34.4 and $65.6 \%$ of the sample households receive and do not receive adequate government support to alleviate food security problems, respectively. Of these households, 35.6 and $34.1 \%$ were food secure and food insecure, respectively. While 64.4 and $65.9 \%$ of the households do not receive government support and become food secure and food insecure, respectively. The chi-square result of this variable is statistically insignificant at $95 \%$ level of significance. Therefore, there is no association between government support and food security status of the rural farm households. This could be attributed to the fact that almost all farmers believed that agricultural production is dependent on natural conditions (climate change and rainfall variability), thereby the analysis of influencing factors of food security is concentrated mainly on such factors than government support. Their idea is supported by a study done in Niger by Barrett (2006). He revealed that food aid decreased government support to agriculture in the long run and caused distortion in the local price of food items.

\section{Determinants of rural household food insecurity: the binary logistic regression model}

This section presents the results of the binary logistic regression and explains the socio-economic, cultural, and physical determinants of rural household food insecurity in the study area. As analyzed and put in order of significance, the dependent variable of the study, household food security status, is a dichotomous variable (food secure and food insecure) and a function of numerous explanatory variables. It assumes that the dependent variable is linearly related to the predictors. As a result, the following 13 potential explanatory variables were selected and hypothesized based on the literature and the author's observation of the study area (Table 5).

\section{Model specification}

As indicated in Table 6, one binary-dependent variable (food security status) and 13 explanatory variables (predictors) were selected for this analysis. Then, the binary logistic regression model was applied to screen out the most significant variables of the study. Therefore, the model is described as:

$$
\ln Y=\ln [Y / 1-Y]=\beta_{0}+\beta_{1} X_{1}+\beta_{2} X_{2}+\beta_{3} X_{3}+\ldots \ldots+\beta_{\mathrm{n}} X_{\mathrm{n}}+\text { ui }
$$

where $\ln =$ natural logarithm, $Y=$ probability of being food secure, $1-Y=$ probability of being food insecure, $\beta_{\mathrm{n}}=$ coefficients of explanatory variables, $X_{\mathrm{n}}=$ predictor variables, and $\mathrm{ui}=$ error term.

The binary logistic regression model was used to investigate determinant causes of rural household food security. The analysis of the survey revealed that 7 out of 13 
Table 5 Description of variables used in the logistic regression model

\begin{tabular}{|c|c|}
\hline Variables & Variables definition and unit of measurement \\
\hline \multicolumn{2}{|l|}{ Dependent variable } \\
\hline$Y=$ HHFSS, food security status & 1 if a household is food secure, 0 otherwise \\
\hline \multicolumn{2}{|l|}{ Independent variables } \\
\hline$X_{1}=\mathrm{GHH}$, gender & 1 if a household head is male, 0 otherwise \\
\hline$X_{2}=H H A$, age & Household head's number of years of age \\
\hline$X_{3}=F S$, family size & Number of household members \\
\hline$X_{4}=N A L F$, agricultural labor force & Number of household members participated in agricultural activities \\
\hline$x_{5}=\mathrm{OFI}$, off-farm income & $\begin{array}{l}1 \text { if the income obtained from off-farm income enabled the household } \\
\text { to buy food crops, } 0 \text { otherwise }\end{array}$ \\
\hline$X_{6}=$ PS, policy support & 1 if the policy support given to achieve food security is high, 0 otherwise \\
\hline$X_{7}=\mathrm{RS}$, relief support & 1 if a household received relief support, 0 otherwise \\
\hline$X_{8}=\mathrm{FE}$, farm experience & $\begin{array}{l}\text { The number of years the household head has engaged } \\
\text { him/herself in farming }\end{array}$ \\
\hline$X_{9}=L R$, land redistribution & 1 if food shortage occurred by periodic land redistribution, 0 otherwise \\
\hline$X_{10}=A E Z$, agro-ecological zone & $\begin{array}{l}1 \text { if food shortage occurred because of their agro-ecological zone } \\
\text { where their farmland is located, } 0 \text { otherwise }\end{array}$ \\
\hline$X_{11}=F L T$, topography & 1 if the farmland topography is gentle, and 0 otherwise \\
\hline$X_{12}=$ soil fertility & 1 if the soil fertility is high, and 0 otherwise \\
\hline$X_{13}=E R$, erosion & 1 if food shortage is occurred by soil erosion, 0 otherwise \\
\hline
\end{tabular}

explanatory variables included in the model were found to be significant in explaining the variation in food security status of respondents. The results confirm that variables such as age of household head $\left(X_{2}\right)$, family size $\left(X_{3}\right)$, number of agricultural labor force $\left(X_{4}\right)$, off-farm income $\left(X_{5}\right)$, relief support/food aid $\left(X_{7}\right)$, farming experience $\left(X_{8}\right)$, and agro-ecological zone $\left(X_{10}\right)$ were key determinants of food security of the rural household. Specifically, the age of household head, family size, off-farm income, relief

Table 6 Results of regression analysis showing determinants of food security

\begin{tabular}{|c|c|c|c|c|c|c|c|c|}
\hline & \multirow[t]{2}{*}{$B$} & \multirow[t]{2}{*}{ S.E. } & \multirow[t]{2}{*}{ Wald } & \multirow[t]{2}{*}{ d.f } & \multirow[t]{2}{*}{ Sig. } & \multirow[t]{2}{*}{$\operatorname{Exp}(B)$} & \multicolumn{2}{|c|}{$95 \%$ C.I. for $\operatorname{Exp}(B)$} \\
\hline & & & & & & & Lower & Upper \\
\hline Gender of household head & -.658 & .554 & 1.411 & 1 & .235 & .518 & .175 & 1.534 \\
\hline Age of household head & -.103 & .039 & 7.146 & 1 & $.008^{*}$ & .902 & .836 & .973 \\
\hline Family size & -.849 & .245 & 12.038 & 1 & $.001^{*}$ & .428 & .265 & 691 \\
\hline Number of agricultural labor force & .603 & .287 & 4.416 & 1 & $.036^{* *}$ & 1.828 & 1.041 & 3.210 \\
\hline Off-farm income & -.874 & .518 & 2.849 & 1 & $.091^{* * *}$ & .417 & .151 & 1.151 \\
\hline Policy support & -.515 & .453 & 1.294 & 1 & .255 & .597 & .246 & 1.452 \\
\hline Relief support (food aid) & -1.465 & .458 & 10.241 & 1 & $.001^{*}$ & .231 & .094 & .567 \\
\hline Farming experience & .091 & .037 & 5.923 & 1 & $.015^{* *}$ & 1.095 & 1.018 & 1.179 \\
\hline Land redistribution & -.464 & .436 & 1.133 & 1 & .287 & .629 & .268 & 1.477 \\
\hline Agro-ecological zone & -.992 & .517 & 3.685 & 1 & $.055^{* * *}$ & .371 & .135 & 1.021 \\
\hline Farm land topography & -.374 & .419 & .795 & 1 & .373 & .688 & .302 & 1.565 \\
\hline Soil fertility & .253 & .430 & .345 & 1 & .557 & 1.288 & .554 & 2.994 \\
\hline Erosion & .738 & 1.237 & .356 & 1 & .551 & 2.093 & .185 & 23.656 \\
\hline Constant & 10.405 & 2.739 & 14.432 & 1 & .000 & $33,010.035$ & & \\
\hline
\end{tabular}

${ }^{*}, * *$, and ${ }^{* *}$ indicate statistical significance at 1,5 , and $10 \%$ probability levels, respectively 
support, and agro-climatic zone had a negative influence on food security of a household. Other variables of significance, namely number of the agricultural labor force and farming experience, were found to exert a positive impact on the determinants of food insecurity. Furthermore, the study identifies food insecurity as a cumulative effect of several factors like population pressure, shortage of farmland, recurrent drought, poverty, climate change, and increasing rate of soil erosion (land degradation), and therefore, policy-makers and other concerned bodies should pay attention to alleviate the problem. The coefficients of variables in the model were significant at $1 \%(p<0.01)$, $5 \%(p<0.05)$, and $10 \%(p<0.1)$ levels of significance, respectively. This indicates that the model was a good fit to the data. The summary of the significant key determinants of food security of rural households is presented in Table 6. However, the gender of household head $\left(X_{1}\right)$, policy support $\left(X_{6}\right)$, land redistribution $\left(X_{9}\right)$, farmland topography $\left(X_{11}\right)$, soil fertility $\left(X_{12}\right)$, and erosion $\left(X_{13}\right)$ do not show any significant influence. The statistical non-significance of these coefficients suggests that these variables are not important in explaining the causes of rural household food insecurity. Particularly, the statistical non-significance of the gender of the household head could be because of the recently introduced women's land ownership right, which enables them to empower economically unlike the past times. Therefore, today, women have an equal right with men on land issues.

The result of the binary logistic regression indicated that age of household head $\left(X_{2}\right)$, family size $\left(X_{3}\right)$, number of agricultural labor force $\left(X_{4}\right)$, off-farm income $\left(X_{5}\right)$, relief support $\left(X_{7}\right)$, farming experience $\left(X_{8}\right)$, and agro-ecological zone $\left(X_{10}\right)$ are significant predictors of rural household food insecurity. Especially, the agricultural labor force has a positive association with the food security status of the household. This implies that the agricultural labor force is imperative as it determines the number of persons engaged in the agricultural activities in order to meet the needs of the household food security.

\section{Age of the household heads}

The mean age of sample household heads is 43 years, ranging from 22 to 75 with a standard deviation of 12.09. The result of the regression analysis for the household head age (HHA) was found to be statistically significant at $1 \%$ level of significance. It is negatively associated with food security status of the rural household. The negative association can be explained by the fact that older farmers are less likely to be food secure. It may be due to the fact that older farmers do not have the required labor force to produce more food crops than their counterparts. This result is in line with the study carried out by Bashir et al. (2012) in Pakistan. They found that an increase of 1 year in the age of household head decreases the chances of a household to become food secure by $3 \%$. Similarly, a study conducted by Omonoma and Agoi (2007) in Nigeria found an inverse relationship between the age of household head and food security. A study carried out by Funmilola and Patricia (2014) in Nigeria also found the same result. They revealed that as the household head advances in age, the probability of being food secure decreases. In contrast, a study done in the USA by Onianwa and Wheelock (2006) revealed that increasing age of household head by 1 year reduces the chances of food insecurity by $2 \%$. A study conducted in Nigeria by Arene and Anyaeji (2010) also come up with similar results. They conclude that the increased age of the household head had a positive effect on food security status. 


\section{Family size}

The average family size of the sample households was found to be 4.3 ranging from 2 to 10 persons with a standard deviation of 1.3. Based on the result of the regression analysis, family size (FS) is statistically significant at $1 \%$. It is negatively associated with rural farm household food security status. The coefficient of this variable explains that an increase in family size by one member decreases the chances of household food security by $42.8 \%$. This result is in line with the results of Bashir et al. (2012), who found that an increase of one member in the household decreases the chances of food security by $31 \%$. This indicates that households with larger family size are more likely to be food insecure than their counterparts. The negative association could be due to an increase in the number of family dependency ratio. This means that households having many children and old age groups may lack sufficient manpower, which eventually results in overdependence on limited family resources hence food insecurity. By taking into account the negative impact of large family size on the food security situation of rural households, farming households should be educated on the importance of family planning and the burden that it causes on their livelihood so that they may bear the number of children which their resources can support. This result is also in agreement with the study conducted in Nigeria by Funmilola and Patricia (2014). They reported that households with large size have a higher possibility of being food insecure than those with smaller size, and vice versa. A study carried out by Robert et al. (2013) in the Sekyere-Afram Plains District of Ghana also came up with similar results. They revealed that the probability of food security decreases with the increase in household size.

\section{Number of agricultural labor forces}

Labor is a key asset for smallholder households in rural Ethiopia. In Ethiopia where farm mechanization is almost non-existent and all farm work is done manually, having access to necessary labor force for agricultural production directly affects the status of rural household's food security. In addition to working on a household's own farm, labor force may also be engaged in off-farm economic activities, thus providing additional income to the household, which could be used for food purchases in times of food shortage.

The mean household members who participated in the agricultural labor force are 2.2 persons ranging from 1 to 5 with a standard deviation of 0.9 . The analysis of this study indicated that the number of the agricultural labor force (NALF) is statistically significant at $5 \%$. The number of the agricultural labor force is one of the major predictors of the causes of rural household food insecurity. It has a positive correlation with food security status of the rural households. This indicates that households with a large number of the agricultural labor force are more likely food secure than their counterparts. Lack of labor force will have an intense impact on agricultural production and household food security. Because of low mechanization in Ethiopian agriculture, human labor is crucial for land preparation, weeding, and harvesting processes. However, in the study area, there are substantial households, whose family members are used to migrate to Arab countries because they thought that it is the best way that brought wealth to rural areas as a form of remittance within a short period of time. There is also temporary migration to nearby towns for daily labor wage benefit. Both of these migration trends can affect agricultural labor force availability. It is thus important for the policy-makers and local government 
administrators to take into account the diversity of rural livelihoods including the provision of credit access at a lower interest rate and job creation so as to improve the food security of the local community in particular and in the region in general. This result is in line with the study done in Nigeria by Funmilola and Patricia (2014). They stated that the higher the participation of the family members in farming activities, the higher the possibility of food security and vice versa.

\section{Off-farm income}

As shown in Table 6, the coefficient of off-farm income (OFI) was statistically significant at $10 \%$ level of significance and exhibited a negative association with food security status of the rural households. The negative association could be due to lack of nonfarm job opportunities and start-up capital constraints. This result is in conformity with the findings of Mitik and Legesse (2014). In their study conducted in southwestern Ethiopia, they indicated that off-farm income is negatively related to household vulnerability and to food insecurity. But the result of this study is inconsistent with the study conducted by Robert et al. (2013) in the Sekyere-Afram Plains District of Ghana. They stated that the coefficient of the off-farm income was positive indicating that there is a positive relationship between off-farm work and food security. Studies conducted by Reardon (1997), Barrett et al. (2001), and Meles et al. (2016) also confirmed similar results. They reported that the success of households and their members in managing food insecurity is largely dependent on their ability to get access to off-farm job opportunities, which could aid as livelihood diversification strategies.

\section{Relief support (food aid)}

In this study, relief support (food aid) means the provision of food grains or cash for food-related purposes to chronically food insecure farm households. This is provided on grant bases to address critical food needs arising from natural and man-made disasters. Food aid is frequently part of the international response to a national or economy-wide extreme crisis. These crises pose an immediate or imminent threat to the lives, livelihoods, short-term stability, and longer-term development.

The survey result of this variable revealed that 34.9 and $65.1 \%$ of the sample households have and do not have received relief support, respectively. The result of the binary logistic regression model indicates that relief support (RS) is statistically significant at $1 \%$ level of significance. It shows a positive association between relief support and food security status of the rural farm households. This result is in line with the findings of Barrett and Maxwell (2005). They argued that food aid contributes to economic development and protects basic human rights, where the aid fills a severe food gap. Food aid transfers play a safety net role by reducing vulnerability and protecting productive assets. In contrast, a study conducted in Niger by Seydou et al. (2014) revealed that food aid influences negatively and significantly the household food security. Similarly, a study done by Demeke et al. (2006) and Gelan (2006) in Ethiopia suggests that food aid displaces domestic production and commercial trade by depressing prices in the recipient countries; it affects the labor supply negatively, enhances market imperfections and information asymmetries, and this, in turn, affects economic development.

\section{Farming experience}

Farming experience is an important factor in determining both productivity and the production level in farming. The mean year of sample household heads farming experience is about 19 years. It ranges from 2 to 60 years having a standard deviation of 12.08 . The 
result of the binary logistic regression model indicates that farming experience (FE) is statistically significant at $5 \%$ level of significance. Therefore, there is a positive association between farming experience and food security status of the rural households. The positive association could be attributed to the fact that farmers who have many years of experience in agricultural activities are more likely to be food secure than their counterparts. This means that as farmers' agricultural experience is increased, their knowledge and skills about sustainable land management and effective utilization of the available small farmlands will be increased as a result able to produce more food crops. This result is in line with the study conducted in Ghana by Kuwornu et al. (2012). They indicated that an experienced farmer is expected to have more insight and ability to diversify his or her production and minimize the risk of food shortage. In addition, an experienced farmer is more likely to have an adequate knowledge of the pest, disease management, and weather. Therefore, the effect of farming experience on food security is likely to be positive. According to Amaza (2006), farming experience on productivity and production may have either a positive or negative effect on agricultural production. This means that up to a certain number of years, the farming experience would have a positive effect on agricultural production; after that period, farming experience may have a negative effect.

\section{Agro-ecological zone}

Practices based on agro-ecological principles include agro-forestry (agricultural systems that combine trees, crops, and animals in order to promote intensification and synergies), water harvesting, livestock integration into farming systems, reduced tillage, composting, and green manure.

As indicated in Table 6, the coefficient of the agro-ecological zone (AEZ) was statistically significant at $10 \%$ level of significance and revealed a negative correlation with food security status of the rural farm households. Therefore, there is no correlation between agro-ecological zone in which sample households farmland is located and their food security status. The negative correlation could be due to lack of adequate information on agro-ecological practices, which can give farmers greater control and enable them to meet their own food needs and boost their incomes. This result is in line with the study done in Jigjiga district of Ethiopia by Hussein and Janekarnkij (2013). They revealed that the agro-ecology stratum in which household's farmland was located found to have a negative and statistically significant impact on food security. However, the integration of trees into annual food crop systems has been adopted by tens of thousands of farmers in Malawi, Zambia, Burkina Faso, and Niger, leading to the increases in household and national food security (Garrity 2010). A recent review of 286 projects in 57 countries found that crop productivity rose by $79 \%$ where farmers had adopted agro-ecological practices (Pretty et al. 2006), while an older study conducted by Pretty and Hine (2001) reported food production rising by $73 \%$ for 4.42 million small-scale farmers growing cereals and root crops.

\section{Causes of food insecurity in the Teleyayen sub-watershed}

The survey results obtained through interview and focus group discussions identified several possible causes of food insecurity. These are shortage of water, poverty, shortage of farmland, drought, population pressure, and shortage of rainfall. Among them, drought, shortage of rainfall, and shortage of farmland are believed to be the major 
causes of food insecurity. Irregular rainfall and low precipitation are the main limiting factors of food crop production. Rainfall is very low and erratic, with periods of drought often followed by devastating flash floods. There are very limited and unevenly distributed water resources in the sub-watershed. Moreover, they are not easily accessible. On the other hand, drought often results in increases in the prices of food crops, and most households who depend only on their own production lack purchasing power to buy food crops to satisfy the needs of their family members. Besides, unreliable spring rainfall aggravates the problem of food security of the area. Most of the time, the summer rainfall starts late and stops early and never resumed. Consequently, such an uneven distribution of the rainfall gives rise to a serious shortage of water during the dry season particularly in the midland (Moist-weyna-dega) agro-ecological zone of the sub-watershed. The insufficient rainfall along with drought usually causes agricultural productivity losses in the subwatershed. Seventy-one percent of the respondents reported that food insecurity is closely related to land degradation. Hence, because of soil fertility and soil erosion problems, agricultural productivity has lowered to the unexpected rate.

\section{Conclusions}

This study examined the determinants of food insecurity in the rural farm households of the Teleyayen sub-watershed case study in Ethiopia. Accordingly, the findings obtained from the study revealed that food insecurity continues to affect the Ethiopian population in general and the sub-watershed communities in particular. The study has found that majority $(79.1 \%)$ of the sample households were found to be food insecure during the period of the survey. The majority of them were younger household heads, who own less than 1 ha of farmland per household. On average, male-headed households are more food secure $(22.09 \%)$ than female-headed households (16.09\%). The food insecurity situation of the study area is extremely difficult and alarming and needs an urgent response. Similar tendency is observed from the descriptive statistics of calorie intake. Several determining factors were identified for the deteriorating food security situation of the study area. They include the shortage of farmland caused by population pressure, recurrent drought, poverty, climate change, shortage of rainfall, and land degradation.

The results of the binary logistic regression confirm that the variables such as age of household head $\left(X_{2}\right)$, family size $\left(X_{3}\right)$, number of agricultural labor force $\left(X_{4}\right)$, off-farm income $\left(X_{5}\right)$, relief support/food aid $\left(X_{7}\right)$, farming experience $\left(X_{8}\right)$, and agro-ecological zone $\left(X_{10}\right)$ were key determinant causes of rural household food insecurity. Especially, the age of household head, family size, off-farm income, relief support (food aid), and agro-climatic zone had a negative influence on food security of the rural households. Other variables of significance, namely number of the agricultural labor force and farm experience, were found to exert a positive impact. This result is also supported by the data obtained from the surveys of the interview and focus group discussions. Accordingly, shortage of water, shortage of farmland, drought, poverty, population pressure, and the shortage of rainfall were identified as possible causes of food insecurity. Irregular rainfall and low precipitation are the main limiting factors of food crop production. Rainfall is very low and erratic, with periods of drought often followed by devastating flash floods. On the other hand, drought often results in increases in the prices of food crops, and most households who depend only on their own production lack purchasing power to 
buy food crops to satisfy the needs of their family members thereby forced to transitory migration in search of wage labor as a daily laborer in the nearby towns. Besides, unreliable spring rainfall aggravates the problem of food security of the area. Most of the time, the summer rainfall starts late and stops early and never resumed. Consequently, such an uneven distribution rainfall gives rise to a serious shortage of water during the dry season particularly in the midland (Moist-weyna-dega) agro-ecological zone of the subwatershed. Therefore, in order to improve the food security situations in Ethiopia in general and in the Teleyayen sub-watershed in particular, actions should be taken as soon as possible. These actions may include expand the family planning education to limit the family size of the rural population, which could ease the problem of overpopulation and acute farmland scarcity and design a strategy to diversify the livelihoods of the rural community so as to complement their food gap.

\section{Endnotes}

${ }^{1}$ Kebele is the smallest administrative unit of Ethiopia

\section{Abbreviations}

AEU: Adult equivalent unit; kcal: Kilocalorie; PSNP: Productive Safety Net Program; SPSS: Statistical Package for Social Sciences

\section{Acknowledgements}

The authors would like to thank both the International Foundation for Science (IFS) and Addis Ababa University for providing financial support to the first author. The authors also would like to extend their deep thanks to all the contributors of this study, namely farmers, local administrators, and development agent workers who took part in the survey.

\section{Authors' contributions}

Both authors read and approved the final manuscript.

\section{Competing interests}

Both authors declare that they have no competing interests.

\section{Publisher's Note}

Springer Nature remains neutral with regard to jurisdictional claims in published maps and institutional affiliations.

\section{Author details}

${ }^{1}$ Department of Geography and Environmental Studies, Wollo University, P.O. Box 1145, Dessie, Ethiopia. ${ }^{2}$ Department of Geography and Environmental Studies, Addis Ababa University, Addis Ababa, Ethiopia.

Received: 7 June 2017 Accepted: 24 April 2018

Published online: 05 June 2018

\section{References}

Amaza SP (2006) Determinants and measurements of food insecurity in Nigeria: some empirical policy guide. Presentation at the International Association of Agricultural Economists Conference, Gold Coast

ANRS-BFED (2008) Amhara National regional State Bureau of Finanace and Economic Development. Annual Statistical Bulletin, Bahir Dar, pp. 29-50.

Arene C, Anyaeji C (2010) Determinants of food security among households in Nsukka metropolis of Enugu State, Nigeria. Pak J Soc Sci 30(1):9-16

Barnett A (2001) Northern Ethiopia: What's the menu? Nutr Food Sci 31(1):35-37

Barrett BC (2006) Food aid's intended and unintended consequences background; paper for food and agriculture organization. Food and Agriculture Organization, Rome

Barrett BC, Maxwell DG (2005) Food aid after fifty years-recasting its role. Routledge, London

Barrett CB, Reardon T, Webb P (2001) Non-farm income diversification and household livelihood strategies in rural Africa: concepts, dynamics, and policy implications. Food Policy 26(4):315-331

Bashir M, Schilizzi S, Pandit R (2012) The determinants of rural food security: the case of landless households of the Punjab, Pakistan. A school of Agricultural and Resource Economics, the University of Western Australia, Crawley

Bouis H (1993) Food consumption surveys: how random are measurement errors? In: Von Braun J, Puet D (eds) Data needs for food policy in developing countries. International food policy research institute, Washington D.C

Bukusuba J, Kikafunda KJ, Whitehead GR (2007) Food security status in households of people living with HIV/AIDS (PLWHA) in a Ugandan Urban setting. British Journal of Nutrition 98 (1):211-217. https://doi.org/10.1017/ S0007114507691806.

Chang HH, Wen Fl (2011) Off-farm work, Technical efficiency and Rice production risk in Taiwan. Agricultural Economics 42(2):269-278. https://doi.org/10.11111/j.1574-0862.2010.00513.x. 
CSA (2007) Summary and statistical report of the 2007 population and housing census of Ethiopia: results at country level. CSA, Addis Ababa

Degefa T (1996) Belg crop production as a strategy of Households' Food security: A comparative study of Belg Grower and non-Belg farmers in Munessa Woreda, Arsi Zone. MA Thesis, Addis Ababa University, Ethiopia

Demeke M, Guta F, Ferede T (2006) "Agricultural development and food security in sub-Saharan; building a case for more public support the case of Ethiopia", prepared for the policy assistance unit of the FAO sub regional office for East and Southern Africa

Derrickson J (2000) Face validity of the core food security module with Asians and Pacific Islanders. J Nutr Educ 32(1):21-30

DFID (2014) Annual review: Ethiopia Productive Safety Net Programme

Doocy S, Teferra S, Norell D, Burnham G (2005) Credit program outcomes: coping capacity and nutritional status in the food insecure context of Ethiopia. Soc Sci Med 60(10):2371-2382. https://doi.org/10.1016/j.socscimed.2004.10.025

Ervin CA, Ervin DE (1982) Factors influencing the use of soil conservation practices: hypotheses, evidence, and policy implications. Land Econ 58(3):277-292

Eshetu B (2000) The underlying causes of household food insecurity and copying strategies. The case of Ligambo Woreda, South Wollo Zone, Amhara region, Northern Ethioia. MA Thesis, Addis Ababa University, Ethiopia

FAO (1984) Ethiopian geomorphology and soils (1:1,000,000 scales). Assistance to Land Use Planning, Addis Ababa np

FAO (1996) Rome declaration on World food security and World food summit plan of action. World food summit 13-17 November 1996. FAO, Rome.

FAO (2002) International scientific symposium on measurement and assessment of food deprivation and under-nutrition. Executive summary. June 26-28. FAO/Food Insecurity and Vulnerability Information and Mapping System, Rome

FAO (2012) The state of food insecurity in the world: economic growth is necessary but not sufficient to accelerate reduction of hunger and malnutrition. FAO, Rome http://www.fao.org/docrep/016/i3027e/i3027e.pdf. Accessed 6 Nov 2017

FAO/WFP (1995) Can Ethiopia feed itself? Crop and food supply assessment mission: proposed travel itinerary; http:// www.africa.upenn.edu/eue_web/assesmis.htm. Accessed 20 Sept 2016

Feleke ST, Kilmer RL, Gladwin CH (2005) Determinants of food security in southern Ethiopia at the household level. Agric Econ 33(3):352-363

Frankenberger T (1992) Indicators and data collection methods for assessing household food security. In: Maxwell S, Frankenberger T (eds) Household food security: concepts, indicators, and measurements: a technical review. UNICEF and IFAD, New York and Rome

Funmilola FA, Patricia OA (2014) Determinanats of food security among low-income households in Maiduguri Metropolis of Borno State, Nigeria. Asian Journal of Social Sciences and Humanities 3(1):74-86. ISSN:2186-8492

Gafsi M, Brossier J (1997) Farm management and protection of natural resources: analysis of adoption process and dependence relationship. Agric Syst 55(1):71-97

Garrity D (2010) Evergreen agriculture: a robust approach to sustainable food security in Africa. Food Security 2:3-20. https://doi.org/10.1007/s12571-010-0070-7

Gelan A (2006) Cash or food aid? A general equilibrium analysis for Ethiopia. Dev Policy Rev 24(5):601-624

Gonfa L (1996) Climate classification of Ethiopia. NMSA, Addis Ababa, pp. 15-58.

Goodwin B, Mishra A (2004) Farming efficiency and the determinants of multiple job holding by farm operators. Am J Agric Econ 86(3):722-729

Gujarati DN (1995) Basic econometrics. $3^{\text {rd }}$ Edn. McGraw-Hill Inc., New York., ISBN-13:9780070252141, p 838

Haileslassie A, Priess J, Veldkamp E, Teketay D, Lensschen JP (2005) Assessment of soil nutrient depletion and its spatial variability on smallholders' mixed farming systems in Ethiopia using partial versus full nutrient balances. Agric Ecosyst Environ 108(1):1-16

Hofferth SI. (2004) Persistence and change in food security of families with children, 1997-1999. Economic Research Institute, USDA, Monograph (EFAN04001). Economic Research Institute, USDA, Monograph (EFAN04001)

Holden S, Shiferaw B, Pender J (2005) Policy analysis for sustainable land management Washington and food security in Ethiopia: a bioeconomic model with market imperfections. International Food Policy Research Institute, D.C.

Hussein WP, Janekarnkij (2013) Determinants of rural household food security in Jigjiga district of Ethiopia. Kasetsart J 34:171-180

IFPRI (2009) Global Hunger Index 2009. International Food Policy Research Institute, Washington, D. C

Kaluski DN, Ophir E, Amede T (2002) Food security and nutrition—-the Ethiopian case for action. Public Health Nutr 5(3):373-381

Kilic T, Carletto C, Miluka J, Savastano S (2009) Rural non-farm income and its impact on agriculture: evidence from Albania. Agric Econ 40(2):139-160

Koffio-Tessio EM, YH Tossou, KA Homevor (2005) Impact of education on agricultural productivity in sub-Saharan Africa. Paper presented at a "Global Conference on Education Research in Developing Countries", Prague, Czech Republic 31 March-2 April

Kothari CR (2004) Research methodology: methods and techniques. $2^{\text {nd }}$ edition. New age international publishers, New Delhi

Kuwornu JKM, Suleyman DM, Amegashie DPK (2012) Analysis of food security status of farming households: in the forest belt of the central region of Ghana. Russ J Agric Socioecon Sci 1(13):26-42

Markos E (1997) Demographic response to ecological degradation and food insecurity in drought prone areas in northern Ethiopia. Ph.D. thesis. the University of Groningen, Amsterday [12], 373, [43] p. (PDOD Publication Series A)

Meles T, Meseret, Miruts M (2016) Assessment of food security status and factors influencing food security in Hawi Guddina district, Ethiopia. Int Sch J 3(3):167-173

Messay M (2009) Causes of rural household food insecurity: a case from Kuyu district, central Ethiopia. Clarion University of Pennsylvania, Clarion, Pennsylvania. J Sustainable Dev Afr 11(4):286-304

Mitik A, Legesse W (2014) The causes and consequences of smallholder farmers' vulnerability to food insecurity in south western Ethiopia. J Bus Econ Manag 2(3):040-046. https://doi.org/10.15413/jbem.2013.0150

MoFED (2002) Ethiopia's sustainable development and poverty reduction program (SDPRD). Ministry of finance and economic development, Addis Ababa http://siteresources.worldbank.org/INTPRS1/Resources/073102.pdf. Accessed 23 June 2016 
NMSA (1996) Climatic and agro-climatic resources of Ethiopia. Vol. 1, no. 1. National Meteorology Service Agency of Ethiopia, Addis Ababa, p 137

Omonoma B, Agoi G (2007) An analysis of food security situation among Nigerian urban households: evidence from Lagos state, Nigeria. J Cent Eur Agric 8(3):397-406

Onianwa OO, Wheelock GC (2006) An analysis of the determinants of food insecurity with severe hunger in selected southern states. South Rural Sociol 21(1):80-96

Pappoe P (2011) Effect of Biofuel production on household food security in the central region of Ghana. M.Sc. Theis, University of Ghana, Ghana

Paudel GS (2001) Farmers' land management practices in the hills of Nepal: a comparative study of watershed 'with' and 'without' external intervention. A dissertation submitted in partial fulfillment of the requirement for the award of doctor of philosophy, Asian Institute of Technology, School of Environment, Resources and Development, Bangkok, Thailand

Phillips T, Taylor (1990) Optimal control of food insecurity: a conceptual framework. Am J Agric Econ 72(5):1304-1330

Pretty J, R. Hine (2001) 'Reducing food poverty with sustainable agriculture: A J. Pretty, A. Noble, D. Bossio, J. Dixon, R. Hine, F.W.T. Penning de Vries, and J

Pretty JN, Noble AD, Bossio D, Dixon J, Hine RE, Penning de Vries FWT, Morison JIL (2006) Resource-conserving agricultural increases yields in developing countries. Environ Sci Technol 40(4):1114-1119. https://doi.org/10.1021/ es051670d

Reardon T (1997) Using evidence of household income diversification to inform study of the rural non-farm labour market in Africa. World Dev 25(5):735-747

Robert A, James O, Mensah Thomas T (2013) Determinants of household food security in the Sekyere-afram plains district of Ghana. First Annual International Interdisciplinary Conference, AllC 2013, 24-26 April, Azores, Portugal-Proceedings

Seydou Z, Liu Y, Baohui S (2014) Factors influencing household food security in West Africa: the case of southern Niger. Sustainability 6:1191-1202. https://doi.org/10.3390/su6031191

UNDP (1994) Emergencies unit for Ethiopia situation report of South Wollo Zone (region 3). http://www.africa.upenn. edu/eue_web/wellomar.htm. Accessed 10 Aug 2015

Urassa JK (2010) Rural household livelihoods, crop production and well-being after a period of trade reforms: a case study of Rukwa, Tanzania. Thesis for award of Ph.D degree at University of Sussex, Brighton, p 232

Webb P, von Braun J, Yohannes Y (1992) Famine in Ethiopia: policy implications of coping failure at national and household levels. International food policy research institute. Research report no. 92. IFPRI, Washington, D.C

Woldeamlak B (2009) Rainwater harvesting as a livelihood strategy in the drought-prone areas of the Amhara regions of Ethiopia. Organization for Social Science Research in Southern and Eastern and Southern Africa (OSSREA), Addis Ababa

\section{Submit your manuscript to a SpringerOpen ${ }^{\circ}$ journal and benefit from:}

- Convenient online submission

- Rigorous peer review

- Open access: articles freely available online

- High visibility within the field

- Retaining the copyright to your article 